\title{
K sporu medzi ekonomickou slobodou a ekonomickou demokraciou ${ }^{1}$
}

\author{
Vladimír Manda \\ Univerzita Konštantína Filozofa v Nitre, SR
}

MANDA, V.: Toward the Disputation Between Economic Freedom and Economic Democracy.

Philosophica Critica, vol. 1, 2015, no. 1, ISSN 1339-8970, pp. 5-20

The aim of this paper is to analyze some aspects of the dispute between modern-day concepts of economic freedom and economic democracy. Economic freedom was highlighted in liberal thinking in the first quarter of the 20th century, especially in the works of L. Mises, in response to the formation of the modern liberalism, which sought in the interests of the welfare state to intervene in the economic sphere of society. The idea of economic freedom as man's individual freedom was highlighted against the entrance of the state into the economic sphere. Advocates of economic democracy became active at the end of the 20th century and beginning of the 21st century, especially under the pressure of the global economic crisis of 2008 and growing wealth inequalities. This paper focuses mainly on the conceptual differences associated with the concept of economic freedom and economic democracy. We are looking for an answer to the question why the concept of economic freedom excludes the concept of economic democracy, when it is clear, that from purely theoretical point of view, the concept of economic freedom and economic democracy have to be mutually conditioned.

Key words: Economic freedom - Economic democracy - Liberalism

Diskusie o l'udskej slobode, ako jednom z hlavných sporných bodov medzi bývalým svetom kapitalizmu, ktorý sa pasoval do role slobodného sveta a socializmu,

1 Príspevok je čiastkovým výsledkom riešenia vedeckého projektu VEGA - 1/0565/13 Idey človeka, slobody a súkromného vlastníctva v sociálno-filozofickom myslení raného novoveku. 
označovaného za neslobodný svet človeka, neutíchajú ani po „vít'azstve slobodného“ kapitalistického systému. Je zaujímavé, aj ked’ nie celkom prekvapujúce, že jednou z významných oblastí diskusie o l'udskej slobode sa stáva sféra ekonomického života buržoáznej spoločnosti. Táto bola tradične v protiklade k bývalej socialistickej plánovito riadenej ekonomike chápaná ako sféra slobodného uplatnenia l'udských síl a kapitálu. Dnes sa však stále viac dostáva do popredia odvrátená stránka ekonomickej slobody, ktorou je prekvapujúco jej nedemokratická povaha. Nedemokratická je spôsobom svojho fungovania, v rámci ktorého je riadená záujmom súkromných vlastníkov a nie záujmom všetkých zúčastnených na ekonomickom procese. Uvedený rozpor súčasne vyvoláva otázku, v akom zmysle je vlastne ekonomická sféra slobodná? Napriek tomu, že spory o povahu ekonomickej sféry buržoáznej spoločnosti siahajú do 19. storočia, vo svojej súčasnej podobe sa objavujú približne v 20. rokoch minulého storočia.

K pionierom ekonomickej demokracie v 20. storočí patrí G. D. H. Cole (18891959), anglický politický teoretik a člen Fabiánskej spoločnosti. Vo svojej práci Guild Socialism (1920) zdôrazňuje, že „demokraciu je potrebné uplatnit' nie len na špeciálnu sféru spoločnosti známu ako ,politika', ale na každú formu sociálnej činnosti a najmä na ekonomiku a priemysel rovnako ako na politické orgány" (Cole 1920, 14). Na druhej strane sa v Rakúsku objavuje práca L. Misesa (1881-1973) Economic Calculation in the Socialist Commonwealth $(1920)^{2}$ ako reakcia na nadšenie vtedajších intelektuálov a politikov pre socializmus nie len v Rakúsku, ale aj Nemecku, Mad'arsku a samozrejme v Rusku, obhajujúca slobodný trh, nezasahovanie štátu do ekonomiky a nutnost' súkromného vlastníctva. Mises ako predstavitel' tzv. Rakúskej ekonomickej školy odmietal Marxov pracovný koncept hodnoty tovaru a presadzoval koncept tzv. subjektívnej hodnoty tovaru. Hodnota tovaru je vytváraná prostredníctvom trhových výmen a závisí v konečnom dôsledku na individuálnom hodnotení kupcov (Mises 2012, 8). To je jeden z kl'účových bodov $\mathrm{k}$ tomu, aby Mises konštatoval, že spoločné vlastníctvo výrobných prostriedkov zničí slobodnú povahu trhovej výmeny, čo sa odrazí na nemožnosti určovat' hodnotu tovarov. Socialistická ekonomika, podl'a neho vedie $\mathrm{k}$ „likvidácii racionality ekonomiky" (Mises 2012, 23). Líniu myslenia presadzujúcu ekonomickú demokraciu možno chápat' ako súčast' širšieho liberálneho sociálno-politického myslenia smerujúceho k predstavám o sociálnom štáte. Tento smer liberálneho myslenia bol už od svojho vzniku v protiklade s tradičným alebo klasickým liberálnym myslením uprednostňujúcim individuálnu, predovšetkým ekonomickú slobodu človeka pred jeho blahobytom. ${ }^{3}$

2 V príspevku sa opierame o anglický preklad Misesovej práce vydaný v roku 2012.

3 Podl'a M. Friedmana sa liberálne myslenie rozštiepilo koncom 19. storočia. Zatial čo liberáli 19. storočia kládli dôraz na l’udskú slobodu tak liberáli 20. storočia začínajú zdôrazňovat' blahobyt človeka (Friedman 1961, 7). Podobný názor má napríklad aj M. 
Zástancovia klasického liberalizmu, dnes nazývaní libertariáni či neoliberáli videli alebo cítili v modernej forme liberalizmu využívajúcej vo vel'kej miere zásahy štátu do ekonomickej sféry potenciálnu hrozbu socializmu, ktorý bol vich očiach pevne spätý práve s regulačnou úlohou štátu voči ekonomickej sfére. ${ }^{4}$

Rozpad socialistickej sústavy oslavovaný v buržoáznych politických kruhoch ako vít’azstvo kapitalizmu a jeho princípov neviedol ani k vyriešeniu vnútorných problémov kapitalizmu a neprispel ani k vyriešeniu sporov medzi obhajcami ekonomickej slobody a ekonomickej demokracie. Skôr, opak je pravdou. Nebývalé rozšírenie kapitalizmu do krajín bývalého socialistického tábora viedlo k posilneniu moci nadnárodných korporácii a k premene korporatívneho kapitalizmu na svetový globálny systém. Strata ilúzií z jeho pôsobenia vo svetovom meradle je jednou z príčin prehlbujúcej sa kritiky kapitalizmu ako aj zdrojom hl'adania nových alternatívnych usporiadaní spoločnosti (Howard - Dubb - McKinley 2014, 231). V tomto smere napríklad známy predstavitel' ekonomickej demokracie D. Schweickart (1942) uvádza, že podnetom pre rozpracovanie teórie ekonomickej demokracie mu boli „,vel'ké protesty proti neoliberálnej globalizácii, ktoré hlboko zarezonovali vo verejnosti v novembri 1999“ (Schweickart 2010, 9). Celosvetová ekonomická kríza, ktorá vypukla v roku 2008 v podobe tzv. hypotekárnej krízy v USA priliala do pôvodnej diskusie medzi klasickým liberalizmom a jeho rôzne sociálne orientovanými odporcami nový „olej“, ktorý diskusiu nie len vyostril, ale v určitom zmysle aj prehĺbil v tom smere, že t’ažisko diskusie sa presúva z otázky, či je dôležitejšia sloboda alebo sociálny blahobyt občanov, na otázky samotného fungovania buržoázneho systému. Daný systém dnes musí riešit' minimálne tri závažné otázky: ako zabránit' d'alším ekonomickým krízam, ako riešit' katastrofálne sa prehlbujúcu majetkovú nerovnost', ktorá ohrozuje demokratické základy buržoáznej spoločnosti a ako systém reformovat' tak, aby sa zabránilo kolapsu globálneho ekosystému (St’ahel 2015).

V príspevku sa nebudeme venovat' všetkým alternatívnym názorom na reformu kapitalizmu. Zameriavame sa len na spor medzi zástancami ekonomickej slo-

Bronfenbrenner $(1955,159)$. V uvedenej súvislosti upozorňujeme aj na nejednotnost' používaných názvov pre predstavitel'ov liberalizmu. My sa budeme držat' rozlíšenia, v rámci ktorého budeme liberálov do 19. storočia označovat' ako tradičných liberálov a liberálov 20. storočia až do súčasnosti diferencovat' na sociálnych liberálov, ktorí uznávajú zásahy štátu do ekonomiky za účelom zlepšenie životných podmienok obyvatel'ov a na neo-liberálov, ktorí vyzdvihujú hodnoty tradičných liberálov, ale na rozdiel od nich sú aj zástancami rôzne obmedzenej demokracie.

4 V zdôrazňovaní socialistického nebezpečenstva skrytého $\mathrm{v}$ zásahoch štátu do ekonomickej sféry života spoločnosti bol okrem Misesa známy predovšetkým F. A. Hayek, ktorý snahy o vedomú reguláciu a plánovanie v ekonomickej sfére chápal ako zavádzanie socialistických metód do buržoáznej spoločnosti (Hayek 1944). 
body a ekonomickej demokracie. Napriek rozmanitým porážkam a prekážkam, myslenie neo-liberálov opierajúce sa predovšetkým o odkaz L. Misesa (18811973), F. A. Hayeka (1899-1992), M. Friedmana (1912-2006) a d'alších, predstavuje aj dnes významnú líniu súčasného sociálno-politického myslenia. Pokial' ide o hodnoty, opätovne vyzdvihujú do popredia význam súkromného vlastníctva, ekonomickú slobodu indivíduí, vládou neregulovaného ekonomického trhu a obmedzenú formu demokracie. Na vzniknuté krízové javy v spoločnosti majú v zásade len jednu odpoved' a tou je potreba ešte väčšej ekonomickej slobody pre pohyb kapitálu, potreba ešte menšej štátnej kontroly ekonomického podnikania.

Na strane druhej sa nachádzajú predstavitelia konceptov ekonomickej demokracie, ktorí sa opierajú predovšetkým o práce a iniciatívu amerického filozofa R. A. Dahla (1915-2014). Dahl vzbudil pozornost' nie len konceptom polyarchie, ale v práci A Preface to Economic Democracy (1985), rázne vyzdvihol požiadavku rozšírenia politickej demokracie aj do ekonomickej sféry v podobe tzv. ekonomickej demokracie. Zdôraznil, že „ak je demokracia oprávnená v riadení štátu, tak potom musí byt' oprávnená aj v riadení ekonomických podnikov a povedat', že demokracia nie je oprávnená v riadení ekonomických podnikov implikuje, že nie je oprávnená ani v riadení štátu“ (Dahla 1985, 111). V súčasnosti je najznámejším predstavitel'om tejto línie D. Schweickart a jeho práca After Capitalism (2002). ${ }^{5}$

Spor medzi vyššie uvedenými predstavitel'mi ekonomickej slobody a ekonomickej demokracie je zaujímavý najmä z pohl'adu teoretického. Z jazykového hl'adiska sa výrazy ekonomická sloboda a ekonomická demokracia javia ako vzájomne sa doplňujúce výrazy, pretože tak, ako by sa mala ekonomická demokracia opierat' o ekonomickú slobodu, platí to aj naopak, ekonomická sloboda by mala umožňovat' ekonomickú demokraciu. Obdobný vzt'ah je napríklad aj medzi politickou slobodou a politickou demokraciou. Tam, kde majú občania politickú slobodu mali by mat' aj možnost' demokratického rozhodovania o otázkach spoločného záujmu. A tam, kde je demokratické usporiadanie, mali by občania disponovat' politickou slobodou. Napriek vyššie uvedenej jazykovej súvislosti termínov ekonomická sloboda a ekonomická demokracia sa v teoretických diskusiách javia ako vzájomne si odporujúce výrazy. Znamená to, že ekonomická sloboda a ekonomická demokracia chápané ako pojmy a nie ako obyčajné jazykové výrazy, si vzájomne odporujú. Otázkou teda je, akým pojmom ekonomickej slobody operujú neoliberáli, ktorí nepripúštajú možnost' ekonomickej demokracie a o aký pojem ekonomickej demokracie sa opierajú jej zástancovia, ktorí chcú ekonomickou demokraciou fakticky nahradit' neoliberálnu ekonomickú slobodu.

5 V príspevku sa opierame o slovenský preklad jeho práce: Po kapitalizme (2010). K reflexii Schweickartovej koncepcie ekonomickej demokracie v slovenskom prostredí pozri napr. (Dinuš - Hohoš 2011) a (Dinuš - Šabíková 2013). 
V predloženom príspevku sa pokúsime ukázat' vecný obsah uvedených pojmov ako aj hlavné dôvody protikladnosti pojmov ekonomická sloboda a ekonomická demokracia. V príspevku budeme postupovat' tak, že najprv sa budeme venovat' otázkam ekonomickej slobody a následne obrátime pozornost' na problematiku ekonomickej demokracie. V závere zhrnieme výsledky, ku ktorým sme dospeli.

\section{Ekonomická sloboda}

Základy ekonomickej slobody v jej liberálnom ponímaní sa formovali už v 16. a 17. storočí, teda v ranom novoveku, a to predovšetkým v Holandsku a Anglicku. Na počiatku svojej „vít’aznej“ historickej cesty sa ekonomická sloboda objavuje v nenápadnej všeobecnej forme majetkovej slobody alebo slobody vlastníka narábat' so svojím majetkom podl'a vlastného uváženia bez toho, aby mu panovník do jeho slobody svojvol'ne zasahoval. Rozvíjajúca sa majetková sloboda čoskoro nachádza aj teoretické zdôvodnenie, a to predovšetkým v sociálno-politickej filozofii J. Locka (1632-1704). Vznik súkromného vlastníctva, v jeho nediferencovanej forme ako osobné vlastníctvo a vlastníctvo výrobných prostriedkov, teda vo forme majetku, nachádza v l'udskej práci. Základom a zdrojom súkromného vlastníctva je, podl'a jeho slávnej tézy to, že každý človek je vlastníkom svojej osoby, nad ktorou má moc len on sám a teda je aj vlastníkom jej praktického uplatnenia, t. j. práce a následne aj jej produktov (Locke 1967, 305). Človek svojou prácou vkladá do predmetu práce, do pracovného materiálu, čast' svojej osoby a tým ju premieňa na čast' seba samého, na čast' svojej osoby ako vec podliehajúcu jeho vôli. Napriek tomu, že dodnes je Lockove chápanie vzniku súkromného vlastníctva jedným z teoretických základov liberálneho myslenia, nepatrí k často citovaným autorom na podporu ekonomickej slobody. Je to vyvolané najmä tým, že v jeho textoch sa síce objavuje majetková sloboda, ale nie ekonomická sloboda, hoci jasné náznaky nezasahovania štátnej moci do ekonomickej sféry sa u neho už nachádzajú. ${ }^{6} \mathrm{Na}$ rozdiel od dnešných liberálov si Locke uvedomoval, že ak osoba vlastní len svoju pracovnú silu a môže sa do určitej miery rozhodovat' o tom, či

${ }^{6}$ Locke sa venoval aj ekonomickým otázkam. V piatom zväzku The Works of John Locke. (London 1823) sa nachádzajú tri ekonomické štúdie: Some Consideration of the Consequences of the Lowering of Interest and the Raising the Value of Money (1691), For encouraging the Coining of Silver Money in England, and after for keeping it here (1695), a Further Consideration concerning Raising the Value of Money (1695). Locke sa tu zaoberá najmä otázkami funkcie peňazí v spoločnosti, otázkami úrokov a dôsledkami jeho štátnej regulácie ako aj otázkami zahraničného obchodu. Ich relatívne systematickým skúmaním sa Locke stal jedným z priekopníkov ekonomickej vedy. 
bude pracovat' alebo nie, či bude pracovat' u jedného alebo druhého zamestnávatel'a, tak táto možnost' vol'by, respektíve takáto sloboda osobe neposkytuje automaticky ani ekonomickú, a v tých časoch, dokonca ani politickú slobodu.

Vlastným teoretickým zdrojom zástancov ekonomickej slobody je predovšetkým práca A. Smitha (1723-1790) An Inquiry into the Nature and Causes of the Wealth of Nations (1776). ${ }^{7}$ V tejto práci sú explicitne zdôraznené tie momenty ekonomickej činnosti, ktoré sa stávajú súčast'ou konceptu ekonomickej slobody. Smith vo svoje práci položil dôraz na nedotknutel'nost' súkromného vlastníctva: „Vlastníctvo, ktoré má každý človek vo svojej práci a ktorá je základom všetkých ostatných foriem vlastníctva, je súčasne aj najsvätejším a nedotknutel'ným vlastníctvom" (Smith 2007, 100). Zdôrazňoval slobodu každého narábat' so svojim vlastníctvom podl'a svojich záujmov, ktorú poníma ako prirodzené právo každého človeka (Smith 2007, 82). Právo slobodne narábat' so svojim vlastníctvom Smith vzt'ahoval nie len na majetok, ale aj na vlastníctvo pracovnej sily. V tomto duchu napríklad zdôrazňuje, že: „Dedičstvo chudobného človeka leží v jeho sile a šikovnosti jeho rúk, a bránit' mu v tom, aby túto silu a šikovnost' využil spôsobom, ktorý považuje za prospešný bez toho, aby poškodil susedov, je čistým násilím na jeho svätom vlastníctve. Je to zjavné zasahovanie do slobody oboch, robotníka ako aj tých, ktorí by ich mohli zamestnat'“ (Smith 2007, 100). Smith sa rovnako jasne vyjadruje aj za nezasahovanie štátu do ekonomickej sféry a domnieva sa, že „systém prirodzenej slobody“, v rámci ktorého je každý človek ponechaný na svoje rozhodovanie, pokial' nezasahuje do práv druhého je ten najlepší systém (Smith 2007, 533). Miestom, kde sa slobodná ekonomická aktivita indivíduí stretáva a prirodzene koordinuje je trh. Napriek tomu, že každý v rámci trhu sleduje svoj vlastný záujem je nútený vstupovat’ do vzt’ahov s druhými preto, lebo svoj vlastný záujem môže uspokojit' len prostredníctvom uspokojenia záujmu druhého. To, čo núti indivíduá k vzájomným ekonomickým vzt’ahom nie je nejaká vonkajšia sila, ale je to ich vlastný záujem a potreba, ktorá ich k tomu núti. V tomto zmysle je trh slobodným trhom, t. j. nie je regulovaný politickými silami (Smith 2007, 349). U Smitha sa nachádza známa idea „neviditel'nej ruky“, ktorá spôsobuje, že napriek tomu, že nikto z účastníkov trhu nesleduje vo svojej činnosti všeobecný záujem celku, neviditel'ná ruka trhu, ktorá pôsobí akoby poza ich chrbát, vedie k rastu bohatstva spoločnosti ako celku (Smith 2007, 349).

Napriek tomu, že u Smitha sa nachádza takmer kompletný koncept ekonomickej slobody, nie je možné ho považovat’ za „kompletného“ liberála. Smith, rovnako ako Locke a d’alší, boli síce zástancami majetkovej, respektíve ekonomickej slobody, ale neboli zástancami individuálnej politickej slobody pre všetkých. Smith je v danej veci vel'mi otvorený a jasný, ked' konštatuje: „Kde je vel'ké bohatstvo, tam je vel'ká nerovnost'. Pretože, kde je jeden vel'mi bohatý človek, tam

7 Pracujeme s elektronickým vydaním z roku 2007. 
musí byt' najmenej pät'sto chudákov a bohatstvo niekol'kých vyvoláva biedu mnohých. Nadbytok bohatého spôsobuje biedu chudákov, ktorí sú často hnaní nedostatkom a povzbudzovaní závist'ou napadnút' majetok boháča. Vlastník bohatstva vysokej hodnoty, ktoré je výsledkom akumulácie práce mnohých rokov a generácii môže každú noc pokojne spávat' len preto, že je pod ochranou občianskeho magistrátu. Celý čas je obkolesený neznámymi nepriatel'mi, pred ktorými môže byt' ochránený len silnou rukou občianskeho magistrátu. Nadobudnutie cenného a rozsiahleho vlastníctva, preto nevyhnutne vyžaduje založenie občianskej vlády. Kde nie je vlastníctvo, vláda nie je potrebná (Smith 2007, 550). V uvedenej súvislosti W. D. Grampp (1965) hovorí o tzv. paradoxe ekonomickej a politickej slobody. Predstavitelia klasickej ekonómie neboli ochotní presadzovat' ekonomický liberalizmus aj do sféry politickej, do podoby všeobecného hlasovacieho práva a kontroly činnosti vlády (Grampp 1965, 50). Boli presvedčení, že človek musí mat' nejaké slobody, ale neboli presvedčení o tom, že všetci by mali mat' rovnakú slobodu (Grampp 1965, 52). K tomu, aby sa liberalizmus mohol stat' všeobecnou teóriou spoločnosti a nie len ekonomickou teóriou, bolo potrebné, aby sa politická sloboda stala všeobecnou slobodou a politická forma usporiadania bola regulovaná všeobecným hlasovacím právom. Ako vieme, na Európskom kontinente k tomu došlo až v 20. storočí a preto neprekvapuje, ak sa medzi liberalizmom 19. a 20. storočia prejavuje rozdiel najmä v tom, že nový liberalizmus neodmieta zasahovanie štátu do ekonomickej sféry (Friedman 1961, 7).

Ekonomická sloboda $\mathrm{v}$ dnešnej podobe je $\mathrm{z}$ vecného hl'adiska len rozvinutím princípov obsiahnutých v Smithovom učení. Je presadzovaná nie len vo sfére politickej, ale je obhajovaná aj rozmanitými akademickými inštitúciami, z ktorých najznámejšie sú Heritage Foundation, Fraser institute, Kochov inštitú a Liberty Fund. ${ }^{8}$ Prvé dva inštitúty pravidelne zverejňujú svoje správy o stave ekonomickej slobody vo svete. Heritage Foundation vydáva v spolupráci s Wall Street Journal tzv. „Index of Economy Freedom“ a Fraser institute vydáva Economic Freedom of the World.

Súčasní obhajcovia ekonomickej slobody nevychádzajú z jednotného pojmového vymedzenia ekonomickej slobody. Napríklad R. A. Lawson (2008) vymedzuje ekonomickú slobodu ako ekonomický systém súkromného vlastníctva a slobodného trhu. Hlavnými prvkami ekonomickej slobody sú osobná vol'ba, dobrovol'ná výmena, sloboda konkurovat' na trhu a ochrana osoby a vlastníctva. T. Miller a A. B. Kim $(2014,79)$ definujú ekonomickú slobodu ako stav, v ktorom každé indivíduum môže konat' s maximálnou autonómnost'ou, samostatnost'ou a s minimálnymi prekážkami v snahe o ich ekonomické živobytie a väčšiu prosperitu. Jadrom každej diskusie o ekonomickej slobode je kritická reflexia vzt’ahu medzi indivíduami a vládou. J. Gwartney, R. Lawson, J. Hall $(2014,1)$ tiež definujú

${ }^{8}$ U nás na Slovensku pôsobí v duchu ekonomickej slobody najmä Nadácia F. A. Hayeka. 
ekonomickú slobodu ako stav, v rámci ktorého majú indivíduá možnost' si volit' ako aj vstupovat' do dobrovol'ných výmen potial', pokial' nepoškodzujú osoby alebo vlastníctvo druhých. Indivíduá majú právo na vol'ný čas, na svoje vlohy a zdroje, ale nemajú právo brat' veci druhým alebo požadovat' od druhých, aby ich zabezpečovali vecami. Použitie násilia, krádeže, klamstva a fyzického napadnutia nie je dovolené v ekonomicky slobodnej spoločnosti, ale inak sú indivíduá slobodné vo vol'be, obchodovaní a spolupráci s druhými a konkurovat' druhým, ako uznajú za vhodné.

Napriek faktu, že jednotlivé koncepty ekonomickej slobody sa vzájomne líšia, zhodujú sa predovšetkým v obhajobe súkromného vlastníctva, v práve vlastníka nakladat' so svojim vlastníctvom podl'a svojich záujmov, v uznaní existencie tzv. slobodného trhu, t. j. trhu, ktorý nie je štátom regulovaný a úlohu štátu fakticky redukujú na zabezpečenie práv vlastníkov. Z hl'adiska štrukturálneho, ekonomická sloboda vystupuje ako systém slobôd sledovaním ktorých je možné merat' ekonomickú slobodu vo svete. Napríklad Heritage Foundation hodnotí krajiny podl'a 4 hlavných skupín znakov. Prvá skupina znakov sa nazýva „Rule of Law“ a vzt'ahuje sa k ochrane vlastníckych práv. Druhá skupina znakov nazývaná „Government Size“ vyjadruje ekonomické náklady vlády. Tretia skupina nazvaná „Regulatory Efficiency“ skúma formy a rozsah zasahovania štátu do slobody obchodu, slobody práce a štvrtú skupinu nazývanú „Market Openness“ tvoria znaky charakterizujúce otvorenost' trhu, slobodu investovania a finančnú slobodu (Index 2015, 91). Kritériá Fraser Institute sú obdobné, ako vyššie uvedené kritériá, ale sa odlišne nazývajú a sú relatívne inak zoskupené. Fraser Institute skúma vel'kost' vlády, právny systém a ochranu vlastníctva, finančnú politiku vlády, slobodu obchodu a reguláciu ekonomickej sféry (Gwartney - Lawson - Hall 2014, 4).

Spoločným znakom konceptov ekonomickej slobody a z nášho pohl'adu aj ich vážnym nedostatkom je to, že ani v jednom prípade nediferencujú rozdiel medzi osobným a súkromným vlastníctvom a v rámci súkromného vlastníctva sa nerobí rozdiel medzi individuálnym súkromným a kapitalistickým súkromným vlastníctvom. ${ }^{9}$ Prehliadanie rozdielu medzi osobným a súkromným vlastníctvom vedie k tomu, že bežné užívanie osobného vlastníctva, napríklad užívanie svojich topánok je chápané ako slobodná ekonomická činnost'. Nerozlišovanie v rámci súkromného vlastníctva medzi individuálnym a kapitalistickým súkromným vlastníctvom má za následok, že sa na ekonomickom trhu nediferencuje medzi postavením vlastníka výrobných prostriedkov, t. j. kapitalistom a postavením vlastníka pracovnej sily, t. j. vlastníkom námezdnej pracovnej sily. V dôsledku prehliadania

\footnotetext{
9 Pod osobným vlastníctvom tu máme na mysli vlastníctvo, ktoré slúži na uspokojovanie osobných potrieb človeka či už je hnutel'né alebo nie. Nie je to vlastníctvo, ktoré človek používa na produkciu ekonomických hodnôt. Osobné vlastníctvo je ohraničené šírkou a kvalitou našich osobných potrieb.
} 
rozdielov vo formách vlastníctva sa vlastník výrobných prostriedkov, či už je to pôda, suroviny, továrne a pod., kladie v rámci trhových slobodných vzt'ahov na rovnakú úroveň ako vlastník pracovnej sily. Z ekonomického hl'adiska je nutné, aby sa výrobné prostriedky, ktoré sú vo vlastníctve jednej osoby a pracovná sila, ktorá je vo vlastníctve inej osoby spojili, pretože bez ich spojenia k žiadnemu ekonomickému procesu nedôjde. To znamená, že majitel' výrobných prostriedkov nebude mat' zisk a vlastník pracovnej sily nebude mat' mzdu. Každý sa rozhoduje vstúpit' do daného procesu dobrovol'ne v tom zmysle, že nie je nejakou vonkajšou fyzickou silou k tomu nútený. Ale „sily“, ktoré ich k tomu vedú sú rôzne. Majitel' výrobných prostriedkov je do procesu hnaný vlastnou predstavou dosiahnutia zisku a robotník je do procesu hnaný tlakom vlastných životných potrieb, tlakom jeho vlastného života. $V$ tomto zmysle A. Moore už v 17. storočí poznamenáva, že zaberanie spoločnej pôdy súkromníkmi, ktoré ostatných oberá o prostriedky na obživu, „dáva chudobným záujem $k$ drine, ktorú by teror nikdy nedokázal“ (Hill 1991, 52).$^{10}$ Vlastník pracovnej sily ide na trh práce nie preto, že sa chce zúčastňovat' konkurencie, že chce podnikat' a dosahovat' zisk, ale preto, aby mohol primeraným spôsobom uspokojovat' svoje životné potreby a potreby svojej rodiny. Vlastník pracovnej sily vstupuje na ekonomický trh nie slobodne, ale z nutnosti. Ak teda skúmame kritériá ekonomickej slobody hlbšie, ukáže sa, že ten, kto z ich realizácie profituje, nie je masa pracovnej sily, ale podnikatelia. Čím je väčšia ekonomická sloboda, t. j. čím menej štát zasahuje, reguluje, zdaňuje atd'., tým viac zisku im ostáva. Z vymedzenia ekonomickej slobody je teda zrejmé, že táto sloboda sa na masu pracovnej sily, ktorá vlieva skutočný „život“ do mŕtveho kapitálu, nijako nevzt'ahuje. Nie je to jednoducho sloboda nakladat's akýmkol'vek majetkom ako chceme.

Sloboda nakladat' s osobným vlastníctvom podl'a svojich potrieb a predstáv je sociálnou a nie ekonomickou slobodou človeka. Sociálna sloboda človeka nespočíva v slobode ekonomicky produkovat', ale v slobode uspokojovat' svoje potreby a záujmy, v slobodne rozvíjat' svoju osobu. Aj sociálna sloboda závisí od rozsahu vlastníctva, ale v danom prípade nejde o vlastníctvo výrobných prostriedkov, ale len predmetov osobnej spotreby. Sociálna sloboda sa objavuje tam, kde má človek vlastníctvo, pomocou ktorého môže uspokojovat' svoje základné a iné osobné potreby. Ekonomická sloboda začína tam, kde sa objavuje vlastníctvo, ktoré môže byt' použité ako kapitál, t. j. na produkciu tovarov a služieb za účelom dosahovania zisku.

Z vymedzenia ekonomickej slobody opierajúcej sa o súkromné vlastníctvo je jasné, prečo liberáli, napriek tomu, že neustále hovoria o ekonomickej slobode, nehovoria nič o ekonomickej demokracii. V súkromných podnikoch ju realizovat'

10 Preto napríklad Marx vo svojom diele Kapitál hovorí o slobode námezdnej pracovnej sily len ako o „formálne slobodnej práci“ (Marx 1985, 628). 
nie je možné, lebo osoby, s ohl'adom na predmet rozhodovania, ktorým je práve rozhodovanie o použití kapitálu, nie sú vzájomne v rovnom a nezávislom postavení. Ani spájanie súkromných vlastníkov do rozmanitých korporácií nie je dôvodom vzniku ekonomickej demokracie, pretože v takýchto korporáciách sa nerozhoduje demokraticky, t. j. v zmysle jedna osoba jeden hlas, ale rozhoduje sa na základe vel'kosti vloženého kapitálu. Rozhoduje ten, kto má viac ako $50 \%$ vloženého kapitálu nezávisle na tom, či je to len jeden vlastník alebo je ich viac.

\section{Ekonomická demokracia}

Koncept ekonomickej demokracie doteraz nemal to št’astie, aby mu bol v dejinách l'udstva poskytnutý priestor na plný rozvoj a to aj napriek tomu, že sa v teoretickej podobe objavuje v rámci rozmanitých konceptov socializmu už od polovice 19. storočia. V podobe politického projektu, ktorý je v určitej opozícii voči ideológii socializmu, tak aj ideológii liberalizmu sa objavuje až v 20. storočí (Malleson 2013, 85). Ekonomická demokracia dnes jestvuje stále len vo forme predstáv a hypotéz, ale nie vo forme ekonomickej reality. My obrátime svoju pozornost' najskôr k teoretickému vymedzeniu ekonomickej demokracie a následne sa budeme venovat' niektorým aspektom Schweickartovej a Ellermanovej koncepcie ekonomickej slobody.

Ak je ekonomická demokracia len inou formou politickej demokracie, na čom sa všetci zhodujú, t. j. je demokraciou, ktorá sa má uplatnit' v ekonomickej sfére, tak by malo platit', že základné princípy demokracie či už vo sfére politickej alebo ekonomickej by mali byt' tie isté. Ekonomická demokracia rovnako ako politická nutne predpokladá slobodné a rovnoprávne indivíduá. V politickej demokracii je sloboda indivídua v tom, že pri svojom rozhodovaní o spoločných politických otázkach nie je podriadené moci žiadneho iného indivídua. Podobne aj v ekonomickej demokracii musia byt' indivíduá vo svojom rozhodovaní ekonomicky slobodné, t. j. ani jedno nemôže byt' podriadené ekonomickej moci iného indivídua. V podmienkach ekonomickej slobody si indivíduá nie sú vzájomne rovné, pretože niektoré indivíduá sú prostredníctvom súkromného vlastníctva podriadené iným. Preto je objektívnou podmienkou uplatnenia ekonomickej demokracie len spoločné a rovné vlastníctvo výrobných prostriedkov. Spoločné znamená, že o ňom môžu rozhodovat' len všetci spoločne a rovné znamená, že pri rozhodovaní o vlastníctve má každý spoluvlastník len jeden hlas, ktorý sa rovná hlasu druhého spoluvlastníka. Uvedené spoločné vlastníctvo nie je sumou individuálnych podielov či už rovných alebo nie, ale povedané rečou niektorých stredovekých teoretikov, je to vlastníctvo, kde každé indivíduum je vlastníkom, ale žiadne nič individuálne nevlastní. 
K demokratickému rozhodovaniu o spoločnom vlastníctve je potrebné, aby rozmanité indivíduá spoločenského celku vytvorili umelú formu svojho spoločenstva, t. j. formu, v ktorej bude každý vystupovat' ako slobodný a rovný vo vzt'ahu k druhému a ktorá im pomôže vyjadrit' ich spoločnú vôl'u. Z hl'adiska politickej demokracie, podobou takéhoto umelého celku je nesporne demokratický štát. V rámci demokratického buržoázneho štátu, ktorý sa v ekonomickej oblasti opiera o súkromné vlastníctvo výrobných prostriedkov, sa demokracia neuplatňuje v ekonomickej sfére, čo vedie k vnútornej rozdvojenosti buržoáznej spoločnosti. Politická sféra je regulovaná demokraticky a ekonomická je regulovaná nedemokraticky, slobodou súkromných vlastníkov.

V časoch existencie socialistického štátu, napriek tomu, že z politického či mocenského hl'adiska nemal v pravom zmysle demokratickú povahu, v ekonomickej sfére boli vytvorené základné predpoklady pre uplatnenie ekonomickej demokracie. ${ }^{11}$ Ústava Československej socialistickej republiky v čl. 8 deklarovala, že štátne vlastníctvo je vlastníctvom všetkého l'udu, t. j. skrze štát môže l'ud ako celok rozhodovat' o svojom vlastníctve. Aj následné zakladanie tzv. národných podnikov, prostredníctvom ktorých štát ako predstavitel' vlastníka delegoval čast' národného majetku do správy zriad'ovaných národných podnikov, bolo v súlade s formovaním ekonomickej demokracie. Avšak na rozdiel od družstevného vlastníctva, kde sa vo vel'kej miere uplatnila ekonomická demokracia vo forme družstevnej demokracie, národné podniky to št’astie nemali. Bolo to podmienené tým, že v ich organizácii a riadení nebola uplatnená ekonomická demokracia, ale štátne direktívne riadenie. Riadenie národného majetku bolo poznačené špecifickým vnútorným rozporom. 0 národnom majetku ako takom, po formálnej stránke, rozhodovali občania prostredníctvom volených orgánov (národné zhromaždenie, krajské, okresné a miestne národné výbory), ale o jednotlivých častiach národného majetku zverených do rúk národným podnikom už nerozhodovali volení predstavitelia vlastníkov, ale štátom poverení zástupcovia.

Ekonomická demokracia, tak ako aj politická demokracia, si vyžadujú demokratické rozhodovanie tak o celku, ako aj o častiach daného celku. Demokratické rozhodovanie o celku je rozhodovaním o všeobecných a záväzných formách vzt’ahujúcich sa na všetky časti celku, v našom prípade, na všetky časti spoločného vlastníctva. Časti celku, okrem spoločných vlastností, majú aj rôzne špecifické vlastnosti, ktoré si vyžadujú osobité, špeciálne rozhodovanie o ich uplatnení v prospech daného celku. Demokratické rozhodovanie o použití špecifických častí celku, napríklad na úrovni podniku, by malo zabezpečit' nielen podriadenie sa

11 Súčasní predstavitelia ekonomickej demokracie pri svojich konceptoch neberú príliš do úvahy skúsenosti nadobudnuté socializmom s plánovaním ekonomiky. Všeobecne, bez hlbšej argumentácie odmietajú socialistický model ekonomiky s výnimkou skúsenosti s modelom robotníckej samosprávy uplatňovaným v bývalej Juhoslávii. 
časti celku, ale zároveň aj rešpektovanie záujmov danej časti v rámci celku. Za socializmu, $v$ časoch existencie spoločného vlastníctva, bola jednota všeobecného a zvláštneho, spoločného a špecifického, nahradená jednostrannou nadvládou všeobecného. Jednotlivé alebo zvláštne sa muselo jednoznačne podriad'ovat' centrálnemu. $V$ danom aspekte treba vidiet' príčinu toho, prečo sa socialistické vlastníctvo nedostalo k plnému rozvinutiu ekonomickej demokracie. Tu je snád' aj jeden z dôvodov, prečo sa občania bývalej Československej socialistickej republiky výrazne nevzpierali tomu, ked” ich „rodiaci“ sa buržoázny demokratický štát formou reštitúcií a privatizácii národného majetku zbavil spoločného národného majetku.

Ako sme uviedli vyššie, k najvýraznejším zástancom ekonomickej demokracie dnes patrí D. Schweickart.12 Vo svojej práci Po kapitalizme (2010), načrtol svoju víziu ekonomickej demokracie, ktorú považuje za určitý model morálneho socializmu (Schweickart 2010, 9). Koncept ekonomickej demokracie, ku ktorému sa dopracoval, by bolo možné zhrnút' do štyroch bodov: zrušenie súkromného vlastníctva výrobných prostriedkov a ich prevedenie do vlastníctva spoločnosti, zamestnanecká samospráva podnikov, uchovanie trhu s tovarmi a službami a spoločenská kontrola investícií (Schweickart 2010, 72). Predložený model sa snaží o určitú symbiózu prvkov kapitalistického a socialistického systému. Zo socialistického systému je to nesporne spoločenské vlastníctvo výrobných prostriedkov, ktoré by spoločnost' prenajímala zamestnaneckým samosprávam. Model zamestnaneckej samosprávy je prevzatý alebo inšpirovaný bývalými samosprávami v Juhoslávii ako aj v súčasnosti jestvujúcimi formami samospráv, napríklad Španielskej spoločnosti Mondragon. Kapitalistickým prvkom v danom modeli ekonomickej demokracie je nesporne snaha o uchovanie trhu pre konkurenciu medzi vyrobenými tovarmi a službami, v čom by mala byt' určitá záruka dosahovania efektívnosti používania výrobných prostriedkov (Schweickart $2010,75)$. V načrtnutom koncepte ekonomickej demokracie je celkom prirodzene viacero nejasných bodov, ale ja by som rád upozornil len na jednu nejasnost'. Schweickart totiž na jednej strane predpokladá, že samosprávne podniky budú dosahovat' predajom svojich tovarov na trhu zisk tak ako v kapitalizme, ale na strane druhej, práca nebude vstupovat' do ceny tovaru ako nákladová položka, ale len ako zvyšková položka. „Práca vystupuje ako zvyšková nároková strana. Pracujúci dostanú všetko čo ostane po zaplatení nepracovných nákladov..." (Schweickart 2010, 76). Pointa je v tom, že či už sa cena práce započíta ako nákladová alebo zvyšková položka do ceny tovaru, započítat' sa musí, lebo potom nie je jasné, ako by cena predaného tovaru mohla zabezpečit' mzdu alebo podiel pracujúcich podniku. Okrem toho Schweickart vymedzuje zisk či už pre kapitalistov

12 Podrobný prehl'ad o súčasnom záujme o problematiku ekonomickej demokracie je možné nájst' u T. Mallesona $(2013,85)$. 
alebo pre samosprávne podniky ako rozdiel medzi „totálnym predajom“ a „totálnymi nákladmi“ (Schweickart 2010, 76). Prehliada fakt, že v kapitalistických podnikoch tento rozdiel je ziskom pre kapitalistu, ale je dosahovaný práve tým, že robotníkovi neplatí za odvedenú prácu, ale mu platí hodnotu jeho pracovnej sily. Zisk potom plynie z toho, že robotník svojim reálnym pracovným výkonom vytvorí väčšiu hodnotu než je hodnota jeho pracovnej sily, ktorú mu kapitalista vyplatí vo forme mzdy. V prípade samosprávnych podnikov, ktoré si ponechajú všetko, čo im ostane po zaplatení „nepracovných nákladov“, im nemôže ostat' nejaký zisk, ale len hodnota práce, ktorú do tovarov vložili. To znamená, že ak by dosiahli či už pozitívny alebo negatívny rozdiel medzi všetkými svojimi nákladmi a príjmami z predaného tovaru, bol by to rozdiel vyvolaný väčšou alebo menšou efektívnost'ou ich výroby oproti ich konkurencii. Teda ich „zisk“ alebo strata by boli súčasne stratou alebo „ziskom“ pre ich konkurentov. Výrazom „zisk“ sa v danom prípade označuje niečo, čo sa kvalitatívne odlišuje svojou podstatou od kapitalistického zisku. ${ }^{13} \mathrm{Z}$ nášho pohl'adu, ciel'om samosprávnych podnikov za predpokladu spoločného vlastníctva výrobných prostriedkov nemôže byt' dosahovanie ziskov. Ich ciel'om by malo byt' efektívne uspokojovanie potrieb spoločnosti. Kto ich bude uspokojovat' najefektívnejšie, ten ostane na trhu a kto nie, musí zaniknút' alebo zvýšit' svoju efektívnost'.

Schweickartov model ekonomickej demokracie samozrejme nie je jediným modelom, v rámci ktorého sa princíp ekonomickej slobody považuje za nedostatočný pre celkový rozvoj spoločnosti. Nesporne zaujímavou postavou zasadzujúcou sa za ekonomickú demokraciu je aj D. P. Ellerman (1993). Tvrdí, že celý západný systém, štruktúra ekonomiky, ktorá sa nazýva kapitalistickou je zlá. Systém je zlý, pretože používa spôsoby a metódy, ktoré sú v rozpore s kapitalistickými inštitúciami. Súčasný ekonomický systém, podl'a neho, porušuje tak princíp súkromného vlastníctva, ako aj princíp demokracie. Základom kapitalizmu je výroba organizovaná prostredníctvom vzt'ahu zamestnávatel' - zamestnanec. Alternatívou tohto systému je trhová ekonomika súkromného vlastníctva, kde každý zamestnáva sám seba alebo sa zamestnávajú spoločne. Organizácie, kde robotníci a manažéri pracujú spoločne pre seba budeme nazývat' „selfemployment firm“ alebo „worker-owned firm“ alebo „a democratic firm“ (Ellerman 1993, 1). Jadrom jeho kritiky je prenajímanie pracovnej sily kapitálom, čím sa, podla Ellermana, porušuje právo indivídua na súkromné vlastníctvo jeho pracovnej sily. Následne ani produkty vlastnej práce danému indivíduu nepatria, lebo v rámci zamestnaneckého vzt’ahu sa vzdáva súkromného vlastníctva svojej pracovnej sily. Preto podl'a Ellermana, ak sa odstráni prenajímanie pracovnej sily kapitálom, tak sa odstráni aj vykorist'ovanie a súčasne vlastník pracovnej sily bude aj vlastníkom produktu svojej práce. K tomu je potrebné, aby na rozdiel od

13 V danej interpretácii sa pridržiavame Marxovho výkladu zisku (Marx 1987, 61-63). 
predchádzajúcej formy zamestnaneckých vzt’ahov, podniky patriace spojeným výrobcom, t. j. „self-employment firms“, si prenajímali kapitál a nie naopak, tak ako je to teraz. Z predaja vyrobených tovarov sa vráti kapitalistovi jeho kapitál a pre seba si ponechá zvyšok (Ellerman 1993, 151-159). ${ }^{14}$

\section{Záver}

Z analýzy ekonomickej slobody v jej liberálnom ponímaní je zrejmé, že je protikladná ekonomickej demokracii. Liberálna ekonomická sloboda je slobodou súkromných vlastníkov dosahovat' ekonomickým použitím svojho vlastníctva zisk. Ekonomická konkurencia alebo boj súkromných vlastníkov o zisk v rámci „slobodného" trhu ukazuje, že zisk jedného je súčasne nevyhnutne stratou druhého a teda sloboda jedného súkromného vlastníka je zároveň obmedzením alebo popretím slobody druhého. Tu, vo sfére ekonomickej konkurencie medzi súkromnými vlastníkmi má svoj pôvod známa liberálna predstava o slobode indivídua ako o priestore, kde sloboda jedného je ohraničená slobodou druhého.

Ekonomická demokracia, ako vízia nového usporiadania ekonomickej sféry života spoločnosti nebuduje na súkromnom vlastníctve, ale na spoločnom a rovnom vlastníctve výrobných prostriedkov všetkými príslušníkmi danej spoločnosti. Spoloční a rovní vlastníci výrobných prostriedkov majú jeden spoločný záujem a preto si nemôžu vzájomne konkurovat' ako vlastníci. Konkurencia sa ich týka len ako konkrétnych výrobcov, ako viac alebo menej efektívnych užívatel'ov zverených výrobných prostriedkov a nie ako vlastníkov. Preto tu do popredia vystupujú ich osobnostné, odborno-praktické schopnosti a zručnosti pri zabezpečovaní potrieb spoločnosti. Ciel'om tejto konkurencie nie je zisk, ale čo najlepšie a najefektívnejšie uspokojovanie potrieb človeka. Ich ekonomická sloboda nemá povahu súkromnej, vzájomne ohraničenej slobody súkromných vlastníkov, ako v prípade liberálnej ekonomickej slobody, ale spoločnej slobody, kde sloboda každého indivídua je sprostredkovaná slobodou iného indivídua.

14 Niektorí autori nachádzajú čiastočnú podporu ekonomickej demokracii aj v prácach J. Rawlsa. Napríklad O’Neill $(2009,379)$ konštatuje, že hoci je Rawls bežne chápaný ako zástanca „welfare state“, tak vo svojich posledných prácach konštatuje, že „welfare state“ nie je schopný plne realizovat' hodnoty spravodlivosti a najmä hodnotu rovných príležitostí a preto voči konceptom „welfare state“ kladie koncept property „owning democracy“, čím zdôrazňuje nutnost' regulácie súkromného vlastníctva demokratickým štátom. 


\section{Literatúra}

BRONFENBRENNER, M. (1955): Two Concepts of Economic Freedom. In: ETHICS, 1955, Vol. LXV, No. 3, pp. 157-170.

COLE, G. D. H. (1920): Guild Socialism. London: Leonard Parsons.

DAHL, R. D. (1985): A Preface to Economic Democracy. California: University of California Press.

DINUŠ, P. - HOHOŠ, L. (eds.) (2011): Svet v bode obratu. Systémové alternatívy kapitalizmu. Bratislava: Veda.

DINUŠ, P. - ŠABÍKOVÁ, K. (eds.) (2013): Ekonomická demokracia dnes. Od teórie k praxi. Bratislava: Veda.

ELlERMAN, D. P. (1993): Property and Contract in Economic: The Case for Economic Democracy. Blackwell Pub.

FRIEDMAN, M. (1961): Capitalism and Freedom. In: New Individualist Rewiev. Indianopolis: Liberty Press Edition.

GRAMPP, W. D. (1965): Economic liberalism. Volume II. New York: Random House.

GWARTNEY, J. - LAWSON, R. - HALL, B. (2014): Economic Freedom of the World. Annual Re-port. Fraser Institute. Online. Web. 15. March. 2015

<http://www.freetheworld.com/datasets_efw.html>

HAYEK, F. A. (1944): The Road to Serfdom. London and New York: Routledge.

HILL, CH. (1991): The World Turned Upside Down. New York: PENGUIN BOOKS.

HOWARD, T. - DUBB, S. - McKINLEY, S. (2014): Economic democracy. In: Achieving Sustainability: Visions, Principles, and Practices, 1st Edition. Rowe, D. (ed) (eBook). Maccmilen Reference USA.

LAWSON, R. A. (2008): Economic freedom. In: The Concise Ecyclo-pedia of Economics. Liberty Fund 2008. Online. Web. 21. March. 2015

<http://www.econlib.org/library/Enc/Economic Freedom.html>

LOCKE, J. (1967): Two Treatises of Government. Cambridge: Cambridge University Press.

LOCKE, J. (1823): The Works of John Locke. In Ten Volumes. Volume V. London.

MARX, K. (1985): Kapitál. Prvý zväzok. Bratislava: Pravda.

MARX, K. (1987): Kapitál. Zväzok tretí. Bratislava: Pravda.

MILlER, T. - KIM, A. B. (2014): Defining Economic Freedom. In: Index Of Economic Freedom. Washington, New York: The Heritage Foundation and Dow Jones \& Company, Inc.

MISES, L. (2012): Economic Calculation in the Socialist Commonwealth. Alabama: MISES INSTITUTE.

O'NEILL, M. (2009): Liberty, Equality and Property-Owning Democracy. In: Journal of Social Science Philosophy. Vol. 40. No. 3., 2009, pp. 379-396.

SCHWEICKART, D. (2010): Po kapitalizme. Bratislava: Spolok slovenských spisovatel'ov. 
SCHWEICKART, D. (1992): Economic democracy: A worthy Socialism that would really work. Science \& Sociaty, Vol. 56, No. 1, 1992, pp. 9-38.

SMITH, A. (2007): An Inquiry into the nature and Causes of the Wealth of nations. MetaLibri. SŤAHEL, R. (2015): Environmentálna zodpovednost' a environmentálna bezpečnost'. In: Filozofia, 2015, roč. 70, č. 1, s. 1-12.

(2015): Index of Economic Freedom. Washington, New York: The Heritage Foundation and Dow Jones \& Company, Inc.

ÚSTAVA ČESKOSLOVENSKEJ SOCIALISTICKEJ REPUBLIKY. Zákon č. 100/1960 Zb. zo dňa 11. 07. 1960. Online. Web. 19. March. 2015 <http://www.zakonypreludi.sk/zz/1960$100>$.

\section{Vladimír Manda}

Katedra filozofie

Filozofická fakulta Univerzity Konštantína Filozofa v Nitre

Hodžova 1

94974 Nitra

Slovenská republika

vmanda@ukf.sk 